\title{
Evaluation of milk and meat quality in culled cows with purulent pododermatitis
}

\author{
Eugene Marin*, Valery Ermolaev, and Oksana Marina \\ Ulyanovsk State Agrarian University named after P.A. Stolypin, 432017 Ulyanovsk, Russia
}

\begin{abstract}
This article presents the results of a sanitary assessment of the quality of milk and meat in culled animals with purulent pododermatitis. The research was conducted in the conditions of a meat processing enterprise. In the selected milk samples from sick animals, the following parameters were studied: consistency, color, taste and smell, acidity, density, fat mass fraction, protein mass fraction, dry skimmed milk residue, the amount of added water and somatic cells in $1 \mathrm{~cm}^{3}$. During the carried-out researches it has been established that animals with purulent polarmarine have skinny fatness, weight ranged from $325 \mathrm{~kg}$ to $463 \mathrm{~kg}$., body temperature fluctuated within the physiological norm and was at the level of 37.9 to $38.7^{\circ} \mathrm{C}$, $\mathrm{pH}$ was at 5.8...6.0, reaction to peroxidase - positive, reactions with copper sulfate solution was benign (meat, the broth was clear, slight turbidity). KMAFANM, CFU $/ \mathrm{cm}^{3}$ fluctuated within $1 * 10^{1} \ldots 1 * 10^{2}$, and bgcp was not detected. In animals with a complicated form of purulent pododermatitis, the consistency of milk does not conform to the permissible values and appeared as a viscous and often flaky liquid. The color ranges from orange to yellow, which is also not allowed, with a putrid smell of milk. The mass fraction of fat in milk in all orthopaedic animals exceeded the permissible values and ranged from 3.32 to $3.71 \%$. The mass fraction of protein in all animals was also higher than normal and was within the range of $2.85 \ldots 3.4 \%$. The Dry skimmed milk residue ranged from $7.70 \ldots 9.53 \%$.
\end{abstract}

\section{Introduction}

Over the past 30 years, diseases in the hoof area in cows has been a very acute and urgent problem for all dairy farming. So, more than $30 \%$ of highly productive cows have typical signs of finger diseases, which are manifested as lameness. Against this background, the service period increases (on average by 30 days), the yield of calves decreases by $18 \%$, culling of sick cows reaches $60 \%$, the average daily milk yield of orthopaedic cows falls by $42 \%$, farms incur huge financial costs for medical measures, as a result of which the rotation in the herd of animals increases, the breeding plan is violated, which affects the breed's gene pool and reduces the profitability of the industry as a whole $[1$, p.61, 2, p.898, 3, p.86, 4, p.22].

This problem is especially exacerbated in the years of transfer of animal husbandry to an industrial basis due to abrupt change in conditions of housing and feeding, in connection with the construction and operation of large livestock farms, where technology of livestock provides basic mechanization of labor-intensive processes, such as distribution of feed, watering, manure removal, the maintenance of the animals without bedding, physical exercise, replacement of roughage - hay, straw for succulent feeds - silage, haylage, concentrates, while reducing the proportion of roughage in the diet. Reducing to a minimum the incidence of surgical diseases in animals is one of the reserves for increasing the profitability of animal husbandry.

To achieve this goal, it is essential to identify the causes of injuries in a timely manner and take the necessary measures to eliminate them; it is possible to detect animals with surgical diseases early, provide them with timely medical care, prevent the development of complications of surgical infection by using the most effective therapeutic and preventive methods and means that will not have a negative impact on the products received, organize optimal conditions for keeping animals, rational feeding them and caring for them $[5$, p.24, 6, p.116, 7, p. 093].

Issues of ensuring the safety of products and animal husbandry facilities occupy an important place, since timely and positive solutions to them guarantee the production, processing, storage and sale of environmentally safe raw materials and products. The solution to this problem is directly dependent on the state of health of farm animals for infectious and noninfectious diseases.

It is important in this context to consider the cultivation of well-known, highly resistant and adapted meat and dairy animals that are not compromised in relation to the most common diseases characteristic of a particular animal species. The consumption of low-

\footnotetext{
Corresponding author: evgenimari@yandex.ru
} 
quality food creates a certain danger to human health. Therefore, improving their sanitary quality, as well as their nutritional and biological value, is of great social importance [8, p.247, 9, p.626, 10, 122].

The purpose of this work was to conduct a sanitary assessment of the quality of milk and meat in culled animals with purulent pododermatitis.

\section{Material and methods}

The research was conducted in the conditions of a meat processing enterprise. The study of physical and chemical indicators of the quality of milk and carcasses in orthopaedic cows was carried out. To do this, the following parameters were studied in milk: consistency, color, taste and smell, acidity, density, fat mass fraction, protein mass fraction, dry skimmed milk residue, the amount of added water and somatic cells in $1 \mathrm{~cm}^{3}$. When determining the smell of cold milk, it is heated in a flask or test tube to a temperature of $25 \ldots 30{ }^{\circ} \mathrm{C}$. In cold milk, the smell is less recognized.

The color of milk is determined in a glass cylinder, by viewing it in reflected light. The consistency is determined by slow transfusion of milk from one container (cylinder, beaker, etc.) to another. Determination of physical and chemical properties of milk (acidity, density, dry residue, fat-free dry residue).

To determine the acidity in a conical flask at $150 \ldots .200 \mathrm{ml}$ is measured with a pipette of $10 \mathrm{ml}$ of milk, by adding $10 \mathrm{ml}$ of distilled water and 3 drops of $1 \%$ alcohol solution of phenolphthalein, the mixture is titrated with a $0.1 \mathrm{n}$ solution of caustic soda until a pink staining appears, which does not disappear for a minute. The number of milliliters of $0.1 \mathrm{n}$ solution of caustic soda, which went to neutralize $10 \mathrm{ml}$ of milk, multiplied by 10 , shows the acidity of the tested milk in degrees of Turner. Before measuring the density, the milk is mixed and carefully poured into a glass cylinder. Without touching the walls of the cylinder, carefully immerse the Clover $\mathrm{M}_{2}$ in the milk. The number of somatic cells in milk was determined using a Cenotest.

Meat research was carried out in accordance with the requirements of the "Rules for veterinary inspection of slaughtered animals, veterinary and sanitary examination of meat and meat products". Sampling for physicochemical, organoleptic and microbiological studies was carried out in a sterile container, microbial contamination of the muscles was also determined, organoleptic studies (appearance, smell, consistency, degree of exsanguination), biochemical and bacteriological studies were conducted. When tasting cooked meat, the smell, transparency and taste of the broth were determined.
The reaction to peroxidase was determined from the physical and chemical indicators of meat quality. A reaction with copper sulfate $\left(\mathrm{CuSO}_{4}\right)$ was also performed. To determine the bacteria groups of Escherichia coli and the total microbial number, we used a unique rapid technology for identifying sanitarysignificant groups of microorganisms - Micro-Snap. The duration of the analysis is from 1 to 7 hours, depending on the complexity of the test sample. Also, in carcasses, the affected limbs were selected for cross-cutting of the limbs in order to visually assess the condition of the affected tissues in the distal limb region.

\section{Results}

During the livestock survey, it was revealed that most often cattle are slaughtered at the meat processing plant for reasons of surgical diseases in the hoof area, which amounts to 80 animals per month or $49.4 \%$ of the number of sick animals received and $8.6 \%$ of the total number of animals accepted by the meat processing plant.

Studying the visual picture of the incidence of orthopedic pathology of animals entering the meat processing plant, we noted ulcerative lesions of the hooves, corolla phlegmon, purulent pododermatitis, purulent arthritis of the hoof joint and bursitis in the hock joint.

Ulcerative lesions of the hooves were characterized by deep progressive soft tissue defects. Basically, ulcers were detected simultaneously on both sites, with the detachment of the Horny Shoe. The ulcers had uneven edges, covered with a liquid, gray, unpleasant-smelling exudate.

The fabrics were a dirty gray color. Severe soreness of the affected limbs caused the cows to fall asleep, and when moving - lameness of the supporting limb of a high degree. Corolla phlegm was mainly accompanied by General animal depression, decreased appetite, and the development of various degrees of lameness. The local temperature was elevated, and the lumen of the interdigital gap was expanded. The phlegmon of the crumb was characterized by the appearance of a spilled swelling in its area with a pronounced pain response and a tendency to form abscesses.

Pus in the foot proceeded in the closed and open forms. The first was accompanied by local inflammatory processes in the base of the skin on the borders of the sole and flesh, changes in the color of the horn and its loosening due to impregnation with inflammatory exudate and necrosis products.

The open form was characterized by a skin defect of a purulent-necrotic nature. In animals, limited mobility was observed, which ended in pronounced lameness. 


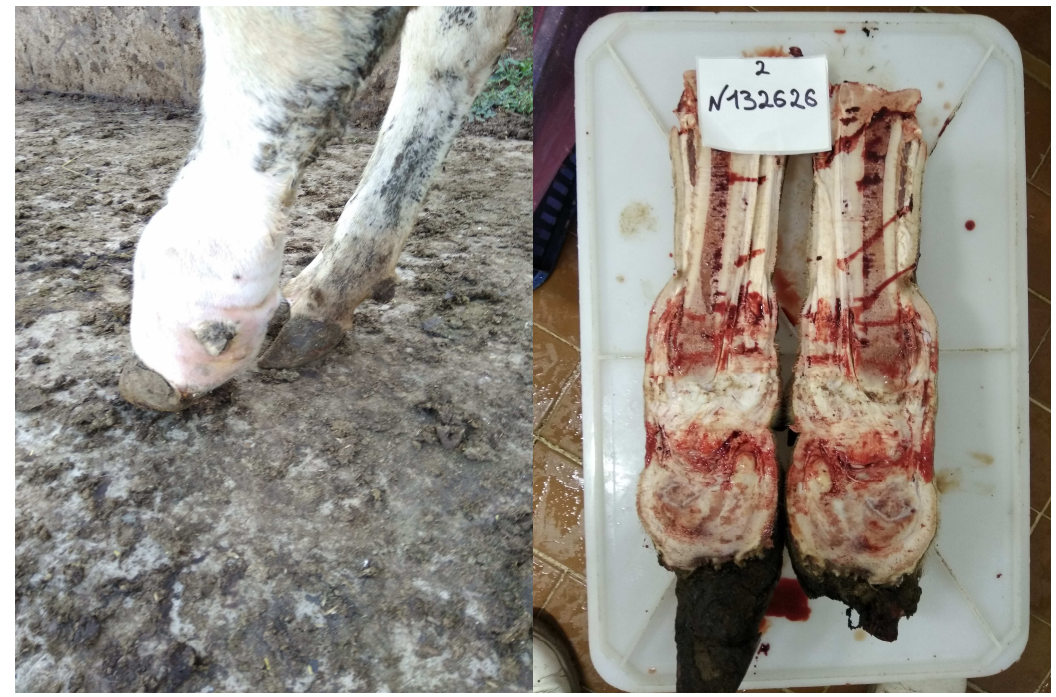

Fig. 1. Cellulitis of the Corolla. Sagittal section of the limb.

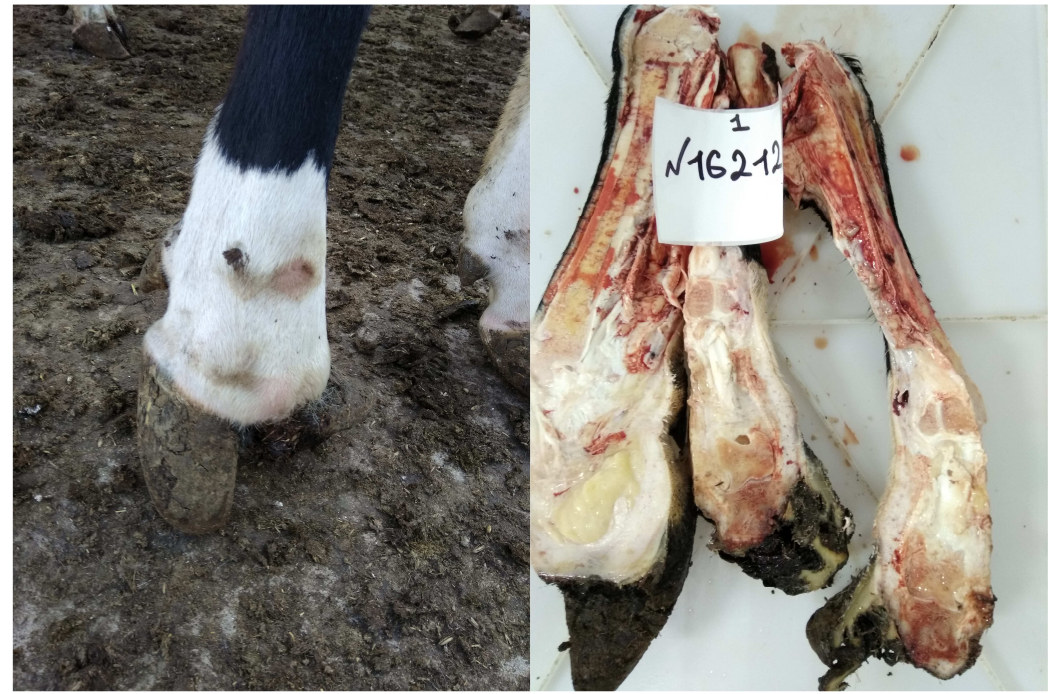

Fig. 2. Purulent pododermatitis. Sagittal section of the limb.

In turn, purulent pododermatitis at the beginning of the disease was manifested by a lesion of one finger, on which the animals did not try to lean during movement, bringing or withdrawing the limb. Often there was a swelling of the sole due to the accumulation of purulentputrid exudate at an angle. In the future, fistulas were opened, through which purulent exudate of a dark gray color was released outwards.

Purulent arthritis of the hoof joint occurred as a complication of Corolla phlegm, purulent pododermatitis, or ulcers of the interdigital fissure. It was characterized by an increase in the volume of the joint, its limited passive movement, severe pain, and edema in the areas of the joint and corolla diverticula. The animals kept the limb taut or fixed it with the edge of the hook. During the movement, the limp of the support type was noticeable. Depression of the General condition and an increase in body temperature were observed.
We selected samples of raw milk from orthopaedic cows that were received for slaughter. The results of the analysis are presented in Table 1 .

In the course of research, it was found that in cows with purulent pododermatitis, the consistency of milk does not correspond to the permissible value and appears as a viscous and often flaky liquid. The color ranges from orange to yellow, which is also unacceptable. The putrid smell of milk was also recorded in sick animals. From the physical and chemical indicators of milk quality, it is necessary to note deviations in the acidity and density of milk up to $1035.8 \mathrm{~kg} / \mathrm{m}^{3}$.

The mass fraction of fat in milk in all orthopaedic animals exceeded the permissible values and ranged from 3.32 to $3.71 \%$. The mass fraction of protein in all animals was also higher than normal and was within the range of $2.85 \ldots 3.4 \%$. the Dry skimmed milk residue fluctuated within $7.70 \ldots 9.53 \%$. SOMO was lowered relative to the acceptable values. 
Table 1. Organoleptic and physico-chemical indicators of milk of cows with purulent-necrotic lesions in the fingers

\begin{tabular}{|c|c|c|c|c|c|c|c|}
\hline \multirow[t]{3}{*}{ No } & \multirow{3}{*}{$\begin{array}{l}\text { Name of the } \\
\text { indicator }\end{array}$} & \multirow{3}{*}{$\begin{array}{l}\text { The permissible } \\
\text { level according } \\
\text { to the normative } \\
\text { documentation }\end{array}$} & \multicolumn{5}{|c|}{ The result obtained, no. of the cow (diagnosis) } \\
\hline & & & 16212 & 132626 & 9645 & 9854 & 18917 \\
\hline & & & $\begin{array}{c}\text { Purulent } \\
\text { pododermatitis }\end{array}$ & $\begin{array}{c}\text { Purulent } \\
\text { pododermatitis }\end{array}$ & $\begin{array}{c}\text { Purulent } \\
\text { pododermatitis }\end{array}$ & $\begin{array}{c}\text { Purulent } \\
\text { pododermatitis }\end{array}$ & $\begin{array}{c}\text { Purulent } \\
\text { pododermatitis }\end{array}$ \\
\hline 1. & Consistency & $\begin{array}{l}\text { Homogeneous } \\
\text { liquid, without } \\
\text { flakes and } \\
\text { sediment }\end{array}$ & $\begin{array}{l}\text { Thick, } \\
\text { viscous, } \\
\text { flakes }\end{array}$ & $\begin{array}{l}\text { Homogeneous } \\
\text { liquid, light } \\
\text { precipitate }\end{array}$ & $\begin{array}{l}\text { Homogeneo } \\
\text { us liquid, } \\
\text { without } \\
\text { flakes and } \\
\text { sediment }\end{array}$ & $\begin{array}{l}\text { Thick, } \\
\text { sticky }\end{array}$ & $\begin{array}{l}\text { Homogeneo } \\
\text { us liquid, } \\
\text { without } \\
\text { precipitation } \\
\text { and flakes }\end{array}$ \\
\hline 2. & Colour & $\begin{array}{l}\text { From white to } \\
\text { light cream }\end{array}$ & $\begin{array}{l}\text { Yellowish } \\
\text { orange }\end{array}$ & Pale pink & White & Yellowish & White \\
\hline 3. & $\begin{array}{l}\text { Taste and } \\
\text { smell }\end{array}$ & $\begin{array}{l}\text { Clean, free } \\
\text { from odors } \\
\text { and taste }\end{array}$ & Putrid smell & No odors & No odors & $\begin{array}{l}\text { There is a } \\
\text { putrid odor }\end{array}$ & No odors \\
\hline 4. & Acidity, gr. T & $14.0 \ldots 21.0$ & 35 & 19 & 17 & 20 & 18 \\
\hline 5. & $\begin{array}{l}\text { Density, } \mathrm{kg} / \\
\mathrm{m}^{3}, \text { not less }\end{array}$ & $1027 \ldots 1030$ & 1035.8 & 1026.54 & 1028.93 & 1027.17 & 1025.98 \\
\hline 6. & M.d. fat, $\%$ & No less 2.8 & 3.32 & 3.71 & 3.24 & 3.61 & 3.51 \\
\hline 7. & $\begin{array}{l}\text { M.d. } \\
\text { protein,\% not } \\
\text { less }\end{array}$ & 2.8 & 3.4 & 2.92 & 3.1 & 2.97 & 2.85 \\
\hline 8. & $\begin{array}{l}\text { Dry skim milk } \\
\text { residue, \% }\end{array}$ & No less 8.2 & 9.53 & 7.88 & 8.33 & 8.03 & 7.70 \\
\hline 9. & $\begin{array}{l}\text { Amount of } \\
\text { added water }\end{array}$ & Not allowed & 0 & 0 & 0 & 0 & 0 \\
\hline 10. & $\begin{array}{l}\text { Somatic cells } \\
\text { in } 1 \mathrm{~cm}^{3}\end{array}$ & $7.5 * 10^{5}$ & $1.8^{*} 10^{6}$ & $8.2 * 10^{5}$ & $4.5^{*} 10^{5}$ & $1.3^{*} 10^{6}$ & $6.5 * 10^{5}$ \\
\hline
\end{tabular}

Table 2. Physico-chemical and microbiological indicators of carcasses with orthopedic diseases

\begin{tabular}{|c|c|c|c|c|c|c|}
\hline \multirow[t]{3}{*}{ No. } & \multirow{3}{*}{$\begin{array}{l}\text { Name of the } \\
\text { indicator }\end{array}$} & \multicolumn{5}{|c|}{ The result obtained, no. of the cow (diagnosis) } \\
\hline & & 16212 & 132626 & 9645 & 9854 & 18917 \\
\hline & & $\begin{array}{l}\text { Purulent } \\
\text { pododermatitis }\end{array}$ & $\begin{array}{l}\text { Purulent } \\
\text { pododermatitis }\end{array}$ & $\begin{array}{l}\text { Purulent } \\
\text { pododermatitis }\end{array}$ & $\begin{array}{l}\text { Purulent } \\
\text { pododermatitis }\end{array}$ & $\begin{array}{l}\text { Purulent } \\
\text { pododermatitis }\end{array}$ \\
\hline 1. & Fatness & skinny & $\begin{array}{ll}\text { below } & \text { the } \\
\text { average }\end{array}$ & skinny & skinny & skinny \\
\hline 2. & Weight, kg & 338 & 463 & 325 & 390 & 329 \\
\hline 3. & Temperature, ${ }^{0} \mathrm{C}$ & 38.7 & 38.2 & 38.4 & 37.9 & 38.3 \\
\hline 4. & $\mathrm{pH}$ & 6.0 & 5.8 & 5.8 & 5.9 & 6.0 \\
\hline 5. & $\begin{array}{l}\text { Peroxidase } \\
\text { Response }\end{array}$ & positive & positive & positive & positive & positive \\
\hline 6. & $\begin{array}{l}\text { The reaction } \\
\text { with a solution } \\
\text { of copper sulfate }\end{array}$ & benign & benign & benign & benign & benign \\
\hline 7. & $\begin{array}{l}\text { KMAFAnM, } \\
\text { CFU/cm }{ }^{3}\end{array}$ & $1 * 10^{1}$ & $1-10^{2}$ & $1 * 10^{2}$ & $1 * 10^{2}$ & $1 * 10^{1}$ \\
\hline 8. & BGKP & Not detected & Not detected & Not detected & Not detected & Not detected \\
\hline
\end{tabular}

All animals with purulent polarmarine had skinny fatness, weight ranged from $325 \mathrm{~kg}$ to $463 \mathrm{~kg}$., body temperature fluctuated within the physiological norm and was at the level of $37.9^{\circ} \mathrm{C}$ to $38.70 \mathrm{C}$, pH was at $5.8 \ldots 6,0$ (the $\mathrm{pH}$ of the meat of healthy animals is in the range of 5.8 to $6.2 \ldots$ and that of ill animals is from 6.3 to 6.5 , in severe cases 6.6 and above), the reaction to peroxidase - positive reactions with copper sulfate solution is benign (meat, the broth was clear, slight turbidity). KMAFAnM, CFU $/ \mathrm{cm}^{3}$ ranged from $1 * 10^{1}$ to $1 * 10^{2}$, and coliforms were not detected.

\section{Conclusion}

Thus, with the diagnosis of surgical diseases in the fingers, animals enter the meat processing enterprise in $8.6 \%$ of cases (based on the culling acts for a month of work). The most common diseases of hooves were purulent-necrotic ulcerative defects, purulent pododermatitis, Corolla phlegmon and arthritis of the 
hoof joint. These surgical diseases in the fingers are the main reasons for culling animals.

When studying the physical and chemical quality indicators of meat carcasses, as well as microbial contamination of carcasses of sick animals, no significant deviations were found. The study of sanitary indicators of milk in orthopedic patients of cows revealed a deviation in organoleptic indicators.

\section{References}

1. E.M. Marin, V.A. Ermolaev, P.M. Lyashenko, A.V. Sapozhnikov, S.N. Hokhlova, A.L. Hokhlov, S.N. Zolotukhin, D.M. Marin, V.I. Ermolaeva, Monitoring of Orthopedic Diseases at Cows, Research journal of pharmaceutical biological and chemical sciences, 8(3), 61-67 (2017)

2. E.M. Marin, V.A. Ermolaev, O.N. Marina, P.M. Lyashenko, A.V. Sapozhnikov, The Microbiocenosis Analysis of Suppurative-Necrotic Ulcers in the Area of Hooves in Cows by PCR Method (Real - Time), Research journal of pharmaceutical biological and chemical sciences, 9(6), 898-903 (2018)

3. V.M. Rukol, A.L. Lyakh, E.V. Khovailo, Pathomorphogenesis of ulcerative lesions of the finger crumb in cows, The issues of normative-legal regulation in veterinary medicine, 3 , 86-89 (2017)

4. A.A. Stekolnikov, B.S. Semenov, Main directions in prevention of surgical pathology in dairy cattle breeding, Veterinary medicine of farm animals, 5-6, 22-28 (2017)
5. D.A. Khuzin, T.R. Gainutdinov, F.A. Khusniev, D.N. Latfullin, N.A. Mukhammetshin, R.D. Khuzin, Diseases of fingers and hooves in cows, their prevention and treatment, Veterinary doctor, 5, 2429 (2014)

6. F.N. Chehodaridi, N.S. Persayeva, M.S. Gugkayeva, Etiopathogenetic therapy of purulent-necrotic ulcers of hooves in cows, Hippology and veterinary medicine, 1(19), 116-120 (2016)

7. L.V. Medvedeva, A.V. Makarov, V.N. Krechetova, State of wound microflora after application of "Sulfacrylate" bioclay for treatment of wounds of distal extremities in cattle, Bulletin of Altai State Agrarian University, 2(100), 093-096 (2013)

8 P. Milosavljevic, V. Savic-Stevanovic, Frequency of some acropodium diseases in dairy cows, Serbia Acta Veterinaria (Beograd), 63(2-3), 247-254 (2013)

9 K.A. Leach, D.A. Tisdall, N.J. Bell, D.C.J. Main, L.E. Green, The effects of early treatment for hindlimb lameness in dairy cows on four commercial UK farms, The Veterinary Journal, 193, 626-632 (2012)

10 A. Ghashghaii, V. Ghasemabadi, M. Javdani, Study on annual and seasonal lameness prevalence in dairy cattle herds of Kermanshah province: the first comprehensive study, in: Proceedings of the first Regional Conference on Cow Comfort and Lameness (RCCCL), pp. 122-123 (University of Tehran, Iran, 2016) 